\title{
Bacterial Isolates from Urinary Tract Infection in Dogs in Grenada, and Their Antibiotic Susceptibility
}

\author{
Harry Hariharan, Erica Brathwaite-Sylvester, Vanessa Matthew Belmar, \\ Ravindra Sharma* \\ Department of Pathobiology, School of Veterinary Medicine, St. George's University, St. George, Grenada \\ Email: hhariharan@sgu.edu, ebrathwaite@sgu.edu,matthewvanessa@hotmail.com, ‘rsharma@sgu.edu
}

Received 19 May 2016; accepted 10 June 2016; published 13 June 2016

Copyright (C) 2016 by authors and Scientific Research Publishing Inc. This work is licensed under the Creative Commons Attribution International License (CC BY). http://creativecommons.org/licenses/by/4.0/

(c) (i) Open Access

\begin{abstract}
Of 52 culture positive urine samples from dogs in Grenada for six years (2004 through 2009) $65.5 \%$ of isolates were Gram-negative bacteria, with $E$. coli as the predominant species, followed by Proteus mirabilis, and Pseudomonas aeruginosa. Other Gram-negative isolates included Klebsiella pneumoniae, Acinetobacter anitratus, and Serratia plymuthica. Among the Gram-positive isolates, Staphylococcus intermedius was the most common species, followed by $S$. aureus, coagulase-negative staphylococci, and enterococci. Sensitivity results obtained with 6 antibiotics showed least resistance to enrofloxacin, the rate being $19 \%$ for all isolates together. More than two-thirds of isolates were resistant to tetracycline. For Gram-positive isolates, resistance to cephalothin was even less than that against enrofloxacin, with a rate of only $13 \%$. Overall resistance to amoxicillinclavulanic acid was $36 \%$. The most common drug used for treatment of urinary tract infections in Grenada has been amoxicillin-clavulanic acid, followed by enrofloxacin.
\end{abstract}

\section{Keywords}

Urinary Tract Infection, Dogs, Bacteria, Antibiotic Susceptibility, Grenada

\section{Introduction}

Bacterial urinary tract infections are the most common cause of urinary tract disease in dogs. Approximately 14\% of all dogs will acquire bacterial urinary tract infection (UTI) during their lifetimes [1]. According to published information, the most frequently isolated bacterium from dogs with UTI is Escherichia coli, followed by

*Corresponding author.

How to cite this paper: Hariharan, H., Brathwaite-Sylvester, E., Belmar, V.M. and Sharma, R. (2016) Bacterial Isolates from Urinary Tract Infection in Dogs in Grenada, and Their Antibiotic Susceptibility. Open Journal of Veterinary Medicine, 6, 8588. http://dx.doi.org/10.4236/ojvm.2016.66010 
Staphylococcus spp., Proteus spp., Streptococcu spp., Klebsiella spp., Enterobacter spp., and Pseudomonas spp [2] [3]. Suggested drugs for treatment of UTI include amoxicillin-clavulanate, trimethoprim-sulfa, cepahlexin, fluoroquinolones, tetracycline, and ampicillin. Alternative drugs include gentamicin and chloramphenicol [3] [4]. Fluoroquinolones such as enrofloxacin are particularly effective in treating UTI due to the high drug concentrations achievable within the urinary tract. In a study in the U.S, over $80 \%$ of urinary tract isolates were found to be susceptible to enrofloxacin [5].

There is no published information on UTI in dogs in Grenada. The aims of this study were to obtain an overview of the species of bacteria suspected to be involved in UTI in dogs in Grenada, and to compare the in-vitro susceptibilites of Gram-negative and Gram-positive bacterial groups to drugs commonly used to treat UTI in the veterinary clinics in this country. For this purpose, we conducted a retrospective study of all submissions of urine samples from dogs to the diagnostic bacteriology unit of the St. George's University (SGU), School of Veterinary Medicine, from the year 2004 through 2009. The laboratory received urine specimens for routine culture and sensitivity testing from the veterinary clinics in Grenada, including the SGU Small Animal Hospital.

\section{Materials and Methods}

Information on sex, and age of each dog, and treatment administered, if any, were collected from the case histories from the year 2004 through 2009. Urine samples were quantitatively cultured and results interpreted as recommended by Osborne [1]. Inoculations were done routinely on blood agar (Columbia agar with 5\% sheep blood, Remel, Lennexa, KS, USA) and MacConkey agar (Remel), using a standard inoculation loop that delivers $0.01 \mathrm{ml}$ or $0.001 \mathrm{ml}$. After incubation at $37^{\circ} \mathrm{C}$ for $18-24$ hours, the plates were examined to determine if cultures were pure or mixed from the colony morphology on blood agar and MacConkey agar, and the colonies were counted. Cutoff values for significant bacteriuria were: $\geq 1000$ colony forming units (CFU)/ml for samples collected by cystocentesis, $\geq 10,000 \mathrm{CFU} / \mathrm{ml}$ for samples collected by cathererization, and $\geq 100,000$ [2].

$\mathrm{CFU} / \mathrm{ml}$ for voided urine. Mixed growth of more than 2 colony types was considered as indicative of contamination. Bacterial isolates were identified by the standard phenotypic characteristics as outlined by Quinn et al. [6]. In case of inconclusive results, API bacterial identification strips (Analytab Products, BioMérieux, MarylEtoile, France) were used. Antimicrobial susceptibility testing was performed by the Kirby-Bauer disk diffusion method, as outlined by Quinn et al. [6] on Mueller-Hinton (MH) agar. The disks used were: amoxicillin-clavu-

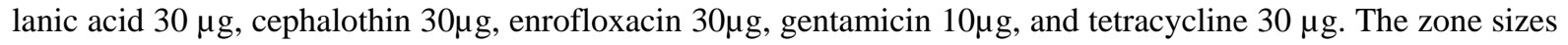
were interpreted as susceptible, intermediate, or resistant, based on the guidelines provided by the Clinical Laboratory Standards Institute (formerly, National Committee for Clinical Laboratory Institute/NCCLS) [7]. For the purpose of analysis, intermediate susceptibility was regarded as susceptible. An E. coli strain ATCC 25,922 (American Type Culture Collection), susceptible to all antibiotics tested, was used as a control.

\section{Results}

Of a total of 151 urine samples cultured, 83 were negative for bacterial growth, and 16 had insignificant growth or mixed growth indicating contamination. Of 52 culture positive samples, indicating urinary tract infection, 30 were from female dogs and 22 from male dogs. The ages of animals varied from 3 months to 14 years, and $75 \%$ of animals were between 3 and 12 years of age. Eighty four percent of urine samples had been collected by cystocentesis. Of 17 samples with a history of antibiotic use, 10 had a course of amoxicillin-clavulanic acid, and 3 had enrofloxacin prior to sample submission. The remaining were on cephalexin, tetracycline, or trimethoprimsulfa.

Table 1 lists the bacteria isolated from the 52 samples, and the percentages of various genera and species. Of the 52 samples, 3 yielded 2 bacterial species. Of the 55 isolates, 65.5\% were Gram-negative bacteria, the most frequent one was E. coli (25.5\%), followed by Proteus mirabilis (18.2\%), and Pseudomonas aeruginosa (10.9\%). Among Gram-positive isolates, the most common species was Staphylococcus intermedius (14.6\%). Each of the remaining species was less than $10 \%$ of total isolates, and included Klebsiella pneumoniae, Staphylococcus aureus, Enterococcus spp., Acinetobacter anitratus, Serratia plymuthica, coagulase-negative Staphylococcus spp., and Streptococccus spp.

The rates of resistance against 6 antibiotics are presented in Table 2. Resistance was least (19.4\%) to enrofloxacin when both Gram-negatives and Gram-positives are considered together. However, when Gram-positives alone are taken into account, resistance was least (13.3\%) to cephalothin. Resistance was highest to tetracycline, 
Table 1. Bacterial isolates from $52^{*}$ urine samples from dogs in Grenada.

\begin{tabular}{ccc}
\hline Isolate & Number & Percent of total isolates \\
\hline Escherichia coli & 14 & $26.9 \%$ \\
Proteus mirabilis & 10 & $18.2 \%$ \\
Staphylococcus intermedius & 8 & $14.6 \%$ \\
Pseudomonas aeruginosa & 6 & $10.9 \%$ \\
Staphylococcus aureus & 5 & $9.1 \%$ \\
Klebsiella pneumoniae & 4 & $7.3 \%$ \\
Enterococcus spp. & 2 & $3.6 \%$ \\
Acinetobacter anitratus & 1 & $1.8 \%$ \\
Serratia plymuthica & 1 & $1.8 \%$ \\
Coagulase-negative Staphylococcus sp. & 3 & $5.5 \%$ \\
Streptococcus spp. & 1 & $1.8 \%$ \\
Total & 55 & $100 \%$ \\
\hline
\end{tabular}

*3 samples yielded 2 isolates in significant numbers.

Table 2. Antibiotic resistance of bacteria from urinary tract infections in dogs.

\begin{tabular}{cccc}
\hline Antibiotic & $\begin{array}{c}\text { Resistant Gram-negative } \\
\text { isolates/number tested }\end{array}$ & $\begin{array}{c}\text { Resistant Gram-positive } \\
\text { isolates/number tested }\end{array}$ & $\begin{array}{c}\text { Total resistant } \\
\text { isolates/number tested }\end{array}$ \\
\hline Enrofloxacin & $5 / 24(20.8 \%)$ & $2 / 12(16.7 \%)$ & $7 / 36(19.4 \%)$ \\
Gentamicin & $9 / 28(32.1 \%)$ & $3 / 10(30 \%)$ & $12 / 38(31.6 \%)$ \\
Cephalothin & $13 / 31(41.9 \%)$ & $2 / 15(13.3 \%)$ & $15 / 46(32.6 \%)$ \\
Amoxicillin-clavulanic acid & $12 / 30(40 \%)$ & $3 / 12(25 \%)$ & $15 / 42(35.7 \%)$ \\
Trimethoprim-sulfa & $2 / 4(50 \%)$ & $2 / 3(66.7 \%)$ & $4 / 7(57.1 \%)$ \\
Tetracycline & $24 / 32(75 \%)$ & $10 / 13(76.9 \%)$ & $34 / 45(75.6 \%)$ \\
\hline
\end{tabular}

the rate being $75.6 \%$. Approximately one-third of all isolates were resistant to amoxicillin-clavulanic acid, cephalothin, and gentamicin.

\section{Discussion}

All 52 culture positive samples, except for 3, had pure growth of a single bacterial species in high numbers indicative of urinary tract infection, and $E$. coli was the most common isolate. These findings are in agreement with the general observation that more than $70 \%$ of UTIs in dogs are caused by a single bacterial species, the predominant isolate being E. coli [8]. UTI is more common in females [9] [10], which is in agreement with our findings.

Among the 6 antibiotics tested, resistance was most frequent to tetracycline. However, a recent study [11], showed that concentrations of doxycycline attained in the urine of dogs were sufficient to inhibit the growth of a significant number (35/45) of urinary tract pathogens. In any case, the present study showed that enrofloxacin had the least resistance; more than $80 \%$ of all isolates being susceptible. This finding is in agreement with that of a study done in the United States [5]. Fluoroquinolones are among the few drugs of choice for treatment of bacterial urinary tract infections in dogs, including those due to Pseudomonas aeruginosa. The disk diffusion method underestimates the effectiveness of some drugs, because it is based on expected serum concentrations. Several drugs, including enrofloxacin reach much higher concentrations in the urine [4]. However, urine culture remains the "gold standard" for diagnosis of urinary tract infection, and culture and susceptibility testing should 
particularly be performed in cases that do not respond within 7 days of therapy [3]. Prior to obtaining culture and sensitivity results, Gram's stain may allow identification of the pathogen as Gram-positive or Gram-negative, and this will be helpful in determining initial therapy [12].

\section{Conflict of Interest}

The authors declare there is no conflict of interest.

\section{References}

[1] Osborne, C.A. (1995) Three Steps to Effective Management of Bacterial Urinary Tract Infections: Diagnosis, Diagnosis, Diagnosis. Compendium, 17, 1233-1240.

[2] Tilley, L.P. and Smith Jr., F.W.K. (2004) The 5-Minute Veterinary Consult-Canine and Feline. 3rd Edition, Lippincott Williams \& Wilkins, Philadelphia, 768-769.

[3] Kruth, S. (2006) Urinary Tract Infections. In: Giguère, S., et al., Eds., Antimicrobial Therapy in Veterinary Medicine, 4th Edition, Blackwell Publishing, Oxford, UK, 372-379.

[4] Bartges, J.W. (2000) Diseases of the Urinary Bladder. In: Birchard, S.J. and Sherding, R.G., Eds., Saunders Manual of Small Animal Practice, 2nd Edition, WB Saunders Co., Philadelphia, 943-957.

[5] Cohn, L.A., Gary, A.T., Fales, W.H. and Madsen, R.W. (2003) Trends in Fluoroquinolone Resistance of Bacteria Isolated from Canine Urinary Tracts. Journal of Veterinary Diagnostic Investigation, 15, 338-343. http://dx.doi.org/10.1177/104063870301500406

[6] Quinn, P.J., Carter, M.E., Markey, B. and Carter, G.R. (1994). Clinical Veterinary Microbiology. Wolf/Mosby, London, 1994.

[7] National Committee for Clinical Laboratory Standards (2002) Performance Standard for Antimicrobial Disk and Dilution Susceptibility Tests for Bacteria Isolated from Animals. 2nd Edition, Approved Standard M31-A2, NCCLS, Wayne, PA.

[8] Barsanti, J.A. (2006) Genitourinary Infections. In: Infectious Diseases of the Dog and Cat, 3rd Edition, Saunders/ Elsevier, St. Louis, MO, 935-961.

[9] WebMD (2015) (webMD.com/dogs. Lower UTI infections-dogs).

[10] Petwave (2015) www.petwave.com

[11] Wilson, B.J., Norris, J.M., Malik, R., Martin, P.A., Wigney, D.I., et al. (2006) Susceptibility of Bacteria from Feline and Canine Urinary Tract Infections to Doxycycline and Tetracycline Concentrations Attained in Urine Four Hours after Oral Dosage. Australian Veterinary Journal, 84, 8-11. http://dx.doi.org/10.1111/j.1751-0813.2006.tb13115.x

[12] Dowling, P.M. (1996) Antimicrobial Therapy of Urinary Tract Infections. Canadian Veterinary Journal, 37, 438-441.

\section{Submit or recommend next manuscript to SCIRP and we will provide best service for you:}

Accepting pre-submission inquiries through Email, Facebook, Linkedin, Twitter, etc

A wide selection of journals (inclusive of 9 subjects, more than 200 journals)

Providing a 24-hour high-quality service

User-friendly online submission system

Fair and swift peer-review system

Efficient typesetting and proofreading procedure

Display of the result of downloads and visits, as well as the number of cited articles

Maximum dissemination of your research work

Submit your manuscript at: http://papersubmission.scirp.org/ 